\title{
Protein Sel-1 Homolog 1
}

National Cancer Institute

\section{Source}

National Cancer Institute. Protein Sel-1 Homolog 1. NCI Thesaurus. Code C105009.

Protein Sel-1 homolog 1 (794 aa, $\sim 89 \mathrm{kDa}$ ) is encoded by the human SEL1L gene. This protein is involved in degradation of misfolded endoplasmic reticulum proteins. 